\title{
As Demandas de Proteção da Sociedade e os Direitos Individuais na Legislação de Saúde- EXEMPLOS DA NORUEGA ${ }^{(*)}$
}

\author{
TRADE-OFF BETWEEN PROTECTIVENEEDS OF SOCIETYANDINDIVIDUAL. \\ RIGHTS IN HEALTH LEGISLATION - EXAMPLES FROM NORWAY
}

Geir Sverre Braut $t^{(\star \star)}$

\section{RESUMO}

Este artigo apresenta a legislação atual relacionada ao tratamento compulsório de pacientes com desordens psiquiátricas e as medidas contra ameças de transmissão de doenças para a saúde na Noruega. O papel do profissional médico é destacado e analisado considerando procedimentos previstos na legislação. O trabalho mostra as necessidades de procedimentos que são usadas para proteger os direitos individuais dos pacientes e 0 julgamento profissional em cada situação, dirigido pelo quadro legislativo.

\section{Palavras-chave}

Legislação em Saúde; Noruega; Modelos Legais; Saúde Pública; Tratamento Compulsório.

\section{ABSTRACT}

This article presents the current legislation related to compulsory treatment of patients with psychiatric disorders and measures against contagious diseases hazardous to public health in Norway. The role of the medical practitioner is enlightened and analysed considering to procedural requirements

(") Artigo baseado em apresentação realizada durante o VII Seminário Internacional de Direito Sanitário, São Paulo, 15 de setembro de 2006. Recebido em 8.1.07. Aprovado em 5.4.07.

$\left({ }^{\star \star}\right)$ Diretor Geral do Comitê Norueguês de Supervisão em Saúde, Oslo, e professor associado de Gerenciamento de Saúde e Segurança da Stord/Haugesund University College. E-mail: $<$ gsb@helsetilsynet.no>. 
in the legislation. It is shown how procedural requirements are used to safeguard the individual rights of the persons concerned and how professional judgements in such situations are governed by the legislative framework.

\section{Key words}

Compulsory Treatment; Health Legislation; Legal Standards; Norway; Public Health.

\section{INTRODUÇÃO}

O objetivo deste artigo é o de utilizar a legislação em saúde vigente na Noruega e a prática administrativa como modelos de caminhos possiveis a fim de definir procedimentos justificáveis para a defesa dos direitos do indivíduo em caso de uma necessidade social de implementar medidas de proteção relacionadas com o ser humano. Os exemplos foram tirados da legislação sobre tratamento compulsório para desordens psiquiátricas e medidas contra doenças contagiosas.

\section{O SISTEMA NORUEGUÉS DE SAÚdE PÚBLICA}

Com uma população de cerca de 4,6 milhões de habitantes, a Noruega é um país pequeno. As estruturas políticas e administrativas e os sistemas relacionados com a área da saúde pública são complexos, porém uniformemente distribuidos por todo o território nacional. A população é etnicamente bastante homogênea; contudo, nas últimas décadas tem ocorrido um aumento no número de imigrações. As habitações dispersas implicam em questões de logística. No entanto, a responsabilidade de prover a saúde básica e os serviços sociais é das comunidades (municipalidades). Atualmente, a Noruega conta com 431 municipalidades, com uma população que varia de 220 mil a 500 mil habitantes. De acordo com a legislação, a responsabilidade pela saúde especializada é das autoridades regionais de saúde, geridas pelo governo. São cinco regionais que supervisionam 40 agências locais, responsáveis, por exemplo, pelos cuidados hospitalares.

A Noruega está em uma situação econômica bastante afortunada, principalmente pela exploração de gás e petróleo no Mar do Norte e na região oceânica do país. Mas, muito antes da "idade do óleo", iniciada nos anos 70 , as bases do atual sistema de saúde pública foram lançadas (em 1945) pelo parlamento norueguês, após decisões freqüentemente consensuais. O modelo do estado do bem-estar social do pais tem como origem o plano Beveridge, da Grã-Bretanha (anos 40). A principal fonte de 
financiamento da saúde pública é o orçamento do governo. O total financiado pela iniciativa privada não é considerável.

Hoje, os gastos da Noruega com saúde pública são vultosos, girando em torno de $10 \%$ do PIB. Pode-se argumentar que são altos demais e que não há como incrementar essa receita ainda mais. Porém, do ponto de vista do paciente, ainda existem muitas falhas no sistema público de saúde norueguês.

As questões mais importantes no debate público sobre os serviços de saúde são: a participação do paciente, acesso local a serviços especializados, qualidade dos cuidados com os idosos e os serviços psiquiátricos comunitários. De tempos em tempos, a priorização surge como um assunto a ser debatido; contudo, ela ainda é tema de alta complexidade difícil de ser abordado, não apenas pelos especialistas em Direito e políticos, como também pelos profissionais da área de saúde. A necessidade de deslocamente das pessoas doentes ("turismo" de pacientes) ainda não emergiu como um grande desafio, como se prevê que ocorra na Europa, em razão da legislação sobre a oferta de serviços entre os países.

\section{ELEMENTOS-CHAVE NA LEGISLAÇÃO EM SAÚDE}

A responsabilidade dos diferentes órgãos públicos envolvidos com a saúde é definida pela legislação. A extensão dos serviços oferecidos em um caso individual é um equilibrio entre a obrigação de fornecer serviços profissionais corretos e a necessidade de cada paciente, de acordo com uma avaliação individualizada.

Segundo a Seção 4 da lei relacionada com a saúde individual, estes serviços devem ser oferecidos com base em boas práticas profissionais. $O$ princípio das boas práticas profissionais deve ser considerado como um "padrão humano razoável", bem conhecido pela lei penal.

A legislação não especifica um padrão de boas práticas profissionais. Esta interpretação deve ser construída com base em julgamentos profissionais correntes, baseados na tradição, evidências científicas e considerações éticas.

A Seção 4, no entanto, é a mais importante regulamentação dos profissionais da saúde na Noruega:

O profissional da saúde deve conduzir seu trabalho de acordo com os requerimentos de responsabilidade profissional e cuidado diligente que, espera-se, tenha como base sua qualificação, a natureza do trabalho e o cenário geral. 
O profissional da saúde deve agir de acordo com suas qualificações profissionais; a assistência aos pacientes pode ser feita por outros profissionais, caso necessário e possivel. Se a necessidade do paciente indicar, o profissional deve trabalhar em cooperação e interação com outro pessoal qualificado.

Além disso, os desejos dos pacientes devem ser levados em consideração e o paciente deve ser capaz de escolher entre possibilidades diferentes de tratamentos justificáveis. Mas, ao paciente não é permitida uma escoIha livre de cuidados de saúde de acordo com seu próprio julgamento ou desejo. A avaliação das demandas do paciente deve ser relatada para julgamento profissional, por exemplo, de um médico ou enfermeiro.

Toda prescrição de cuidados de saúde deve ser fundamentada no consentimento válido do paciente. Desvios deste princípio necessitam de uma autorização por escrito. Dois exemplos desta situação serão descritos a seguir.

Finalmente, é importante mencionar que o sistema legislativo norueguês é baseado no estatuto da Europa Central. A legislação conhecida como anglo-americana não é o guia principal, mesmo que haja argumentos de que o uso extensivo de padrões legais têm alguma semelhança com ela e está baseado em sua tradição.

\section{REGRAS PARA A PRÁTICA MÉDICA}

A primeira legislação relativa à prática da Medicina da Noruega data de 1672, e ela define ao menos dois papéis diferentes para a prática médica. Ainda hoje, podem-se identificar estes papéis na legislação corrente.

O primeiro deles é o de "clínico", que atua na investigação médica, prescrevendo tratamentos de acordo com as necessidades de um paciente, com base em conhecimento profissional, perfis e atitudes. A norma condutora deste clínico é a de agir em interesse do doente. Certamente, esta é uma parte central da tradição Hipocrática.

Já o segundo papel, é identificado como "servidor público de saúde", que atua no âmbito da sociedade, indicando medidas médicas de regulação e controle.

Esses dois papéis não são sempre fáceis de combinar, nem de um ponto de vista prático, nem ético. A possibilidade de considerações éticas relacionadas ao conflito de interesses não será tema de discussão deste artigo, apesar de sua importância. Neste trabalho, destaca-se apenas que, se na prática médica, o "clínico" quiser se engajar em outras atividades, além daquelas do puro interesse do paciente, esta ação deve ser autorizada pela lei. 
Na legislação norueguesa, o papel de "servidor público" é iminente em uma série de situações, como, por exemplo, nas avaliações médicas para concessão de habilitação ou para a definição de pensões em caso de afastamento do trabalho por motivos médicos. Os casos de pacientes com sérios distúrbios mentais e doenças contagiosas serão discutidos a seguir.

\section{TRATAMENTO PSIQUIÁTRICO COMPULSÓRIO}

A legislação corrente relacionada com o tratamento compulsório de pacientes com distúrbios psiquiátricos é de 2001. A nova legislação tem como foco os direitos do paciente durante o processo de decisão por um tratamento compulsório. Depois de uma avaliação, esta legislação foi revisada pelo Parlamento em dezembro de 2006. Durante esta revisão, os direitos do paciente foram ainda mais esclarecidos.

O princípio fundamental diz que os pacientes que necessitam de cuidados psiquiátricos devem recebê-lo, assim como os outros tipos de cuidados com a saúde, com base em consentimento válido e por intermédio da oferta de serviços de acordo com as boas práticas profissionais. Somente se não for possivel esse consentimento, a investigação clínica ou tratamento compulsório deverão ser considerados.

Os requerimentos relacionados com a investigação clínica compulsória não serão considerados aqui. Para implementar um tratamento compulsório, a lei de cuidado psiquiátrico especifica os seguintes critérios absolutos:

- o paciente deve ter um distúrbio psiquiátrico de ordem grave (na prática, interpretado como psicose) e em razão desta doença:

- o paciente não deve apresentar possibilidades de uma recuperação significativa ou, em resumo, constitui um sério perigo para sua própria vida ou saúde, ou para as de outras pessoas.

Esses critérios devem ser analisados com base em julgamento profissional. Para que este julgamento seja válido, não basta ser feito de acordo com as boas práticas médicas. É necessário também que seja realizado de acordo com procedimentos específicos, descritos pela legislação.

Em primeiro lugar, a investigação clínica deverá ter sido solicitada pelos parentes do paciente ou por uma autoridade pública. A relevância da autoridade e as posições dos parentes que podem solicitar essa investigação são definidas pela legislação.

Em seguida, a investigação clínica primária deverá ser realizada por um profissional médico que não esteja vinculado à instituição psiquiátrica que potencialmente cuidará do paciente. 
Os resultados dessa investigação devem ser apresentados por escrito para a instituição psiquiátrica. Esse julgamento não é considerado como uma decisão pública. Mas, como uma avaliação profissional dada por um profissional médico e deve ser utilizado para a análise, por parte da autoridade de saúde pública (Colegiado Norueguês de Supervisão em Saúde, em inglês: Norwegian Board of Health Supervision).

Em terceiro lugar, um psiquiatra (ou psicólogo) deve concordar com o julgamento do primeiro investigador de que os critérios que definem a necessidade de um tratamento compulsório tenham sido preenchidos. Esta avaliação deve ser feita de acordo com uma investigação médica pessoal do paciente, independentemente da primeira avaliação. Além disso, uma decisão formal deve ser feita se o tratamento compulsório for aprovado.

A decisão de implementar um tratamento compulsório deve ser documentada e apresentada ao paciente com a informação dos procedimentos requeridos. Esta é considerada uma decisão pública feita pelo hospital em nome do Estado (governo).

Por fim, esta decisão deve ser solicitada, primeiro, a uma corte especial e, em seguida, junto a instâncias ordinárias.

A cada passo desse processo, o paciente deve ser informado e devem ser dadas oportunidades para que ele possa se posicionar com relação à situação. Além disso, o paciente é estimulado a contratar um advogado para assisti-lo. Os custos relativos a este serviço são cobertos pelas autoridades públicas.

\section{MEDIDAS COMPULSÓRIAS RELACIONADAS COM DOENÇAS CONTAGIOSAS}

A legislação vigente com relação às doenças contagiosas é de 1994. A decisão relacionada com a proteção contra as doenças contagiosas substituiu uma série de diferentes atos e regulações, sendo a mais antiga de 1860 . O formato de diferentes leis para diferentes doenças (como, por exemplo, uma para tuberculose e outra para DSTs) foi abandonado. Todas as formas de doenças e medidas públicas são cobertas pela nova legislação.

As doenças contagiosas emergentes, com exceção da AIDS, apresentam desafios não previstos pela legislação anterior. Uma das principais preocupações era que a antiga legislação não definia nenhuma norma relacionada à investigação clínica compulsória, tratamento ou isolamento de indivíduos. Como resultado, não há procedimentos específicos na lei.

Os objetivos da regulação de proteção contra doenças contagiosas são proteger a população contra estas doenças, garantindo a informação e 
o tratamento dos pacientes, regulamentando medidas compulsórias relacionadas com as pessoas e definindo responsabilidades para diferentes atores e instituições.

O conjunto de possibilidades de medidas compulsórias inclui investigação médica para diagnosticar as moléstias, isolamento em hospital, imunização e impedimento para trabalhar, por exemplo, na indústria alimentar ou no segmento da saúde.

Medidas compulsórias são possiveis apenas se a doença em questão for vista como uma moléstia contagiosa e uma ameaça à saúde pública, conforme definido pela legislação.

A lei esclarece também os direitos e obrigações dos pacientes ou possiveis pessoas infectadas, incluindo o direito de acesso à informação e à assistência médica, vacinação e tratamento. Entre as obrigações está o dever do paciente de contatar um profissional médico o mais rápido possivel quando existem suspeitas de uma doença contagiosa. Também há o dever do paciente de seguir as prescrições médicas.

De acordo com essa legislação, assim como no caso de tratamento psiquiátrico compulsório, medidas voluntárias de cooperação devem ser tentadas e aplicadas para a prevenção de contágio e são justificadas com base no conhecimento médico e não impostas sem razão e são restritas a um determinado período de tempo.

A autoridade municipal tem uma posição central, segundo essa legislação. Ela é obrigada a iniciar o trabalho junto aos pacientes quando necessário e atuar em conjunto com um especialista em doenças infecciosas na avaliação dos casos individuais. Destaque-se que essa autoridade municipal é tipicamente um profissional médico especializado em saúde coletiva.

O julgamento profissional desses dois médicos deve ser encaminhado para uma comissão nacional, por meio das autoridades governamentais regionais (governador ou secretário de saúde). A comissão nacional toma as decisões formais em cada caso. Esta decisão pode sofrer recursos na justiça comum. O paciente deve contar com a assistência de um advogado, de sua própria escolha, e os gastos relacionados com esse serviço são custeados pelo governo.

\section{DISCUSSÃO}

As restrições aos direitos individuais por razões médicas são quase sempre necessárias para a proteção do interesse público. Os dois conjuntos de normas apresentados mostram alguns princípios comuns utilizados na legislação da Noruega para fazer um intercâmbio entre as liberdades individuais e as necessidades públicas. Estes princípios podem ser resumidos como segue: 
- O princípio fundamental diz que, se é possível conseguir a cooperação voluntária do paciente, as intervenções médicas devem ser baseadas em consentimento válido.

- As possiveis restrições para o indivíduo devem ser baseadas no conhecimento médico corrente e no princípio geral da legislação em saúde da Noruega, pelo qual todos os serviços devem estar de acordo com as boas práticas profissionais.

- As restrições não devem se estender no tempo e o conteúdo deve ser razoável, em relação aos propósitos das medidas.

- As pessoas que sofrerão restrições a sua liberdade devem usufruir de cuidados médicos dentro dos melhores padrões de qualidade (e gratuitamente).

- O processo que leva às restrições deve ser definido na legislação. Ele deve ser previsivel, transparente e documentado caso a caso.

- As decisões devem ser cabíveis de sofrerem recursos, não apenas em um órgão administrativo, como também na justiça comum.

\section{CONCLUSÃO}

O papel do profissional médico como um controlador, em nome da sociedade, deve ser constantemente fiscalizado. Os limites do poder de um médico devem ser claramente definidos pela legislação e subordinados aos direitos do paciente.

Isso quer dizer que os profissionais médicos, pela sua educação, não apenas devem adquirir conhecimento e habilidades na perfomance de julgamentos médicos, como também adquirir conhecimentos do cenário no qual se faz esses julgamentos. As avaliações médicas devem ser definidas por "padrões legais" e os procedimentos devem ser claramente expressos por meio de um estatuto legal.

\section{REFERÊNCIAS}

JOHNSEN, Jan Roth. Norway. Health systems in transition: Norway. Copenhagen: WHO Regional Office for Europe on behalf of the European Observatory on Health Systems and Policies, 2006.

MOLVEN, Olav (Ed). Health legislation in Norway. Oslo: University of Oslo; Centre for Medical Studies, Moscow, 2002.

NORWEGIAN BOARD OF HEALTH SUPERVISION. Annual supervision report 2005. Oslo, 2006. Disponível em: <www.helsetilsynet.no>. 
SYSE, A. Norway: valid (as opposed to informed) consent. Lancet, v. 356, p. 1347-1348, 2000.

UNIVERSITY OF OSLO. Translated Norwegian legislation. Disponivel em: $<$ <ttp://www.ub.uio.no/cgi-bin/ujur/ulov/sok.cgi?type=LOV>.

\title{
VERSÃO EM INGLÊS
}

\section{Trade-off Between Protective Needs of Society and Individual Rights in Health Legislation - EXAMPLES FROM NORWAY ${ }^{(*)}$}

\author{
Geir Sverre Braut ${ }^{\star \star)}$
}

\section{PURPOSE}

The purpose of this article is to use current Norwegian health legislation and administrative practice as an illustration of possible ways to design. justifiable procedures for defending the rights of the individual when there is a need for the society to implement protective measures concerning human beings of medical causes. The examples will be taken from legislation concerning compulsory treatment of serious psychiatric disorders and measures against contagious diseases.

\section{THE NORWEGIAN HEALTH CARE SYSTEM}

Norway is a small country, with only about 4.6 million inhabitants. The political and administrative structures and systems for delivery of health care are quite complicated, but uniform across the country. The population is ethnically very homogenous, but last decades immigration has been increasing. Scattered habitations pose logistic problems. Therefore the responsibility for provision of primary health and social services by legislation is placed upon the local communities (municipalities). There are at present

(*) Article based on presentation given at VII Seminário Internacional de Direito Sanitário, São Paulo, September 15, 2006.

(**) Deputy Director General, Norwegian Board of Health Supervision, Oslo, Norway and Associate Professor of Health and Safety Management, Stord/Haugesund University College. E-mail: $<$ gsb@helsetilsynet.no>. 
(2007) 431 municipalities in Norway, with from only 220 to over 500.000 inhabitants. Provision of specialised health care is by legislation the responsibility for regional health authorities owned and governed by the government. There are 5 regional health authorities with together over 40 subordinate local health enterprises responsible for the actual provision of e.g. hospital care.

Norway is in a very fortunate economic situation, not least because of the oil and gas exploration of the North Sea and the Norwegian Ocean. But far before the "age of oil", beginning in the 1970ies, the foundations of present the public health services were laid from 1945 by the Norwegian parliament, mostly through decisions based upon broad political consensus. The model for welfare development chosen in Norway is originally based upon the Beveridge-plan from Great Britain in the 1940ies. The main financial source for the health services is through public (governmental) budgets. The amount of purely private financed health care is negligible.

Today the Norwegian expenditure on health services is very high, around $10 \%$ of the gross domestic product. It may be argued that it is too high, and that there is no point in increasing the expenses even more. Still there are many shortcomings identified in the Norwegian health services seen from the patient point of view.

Hot topics in the public debate upon health services are patient's participation, local access to specialised services, quality of care for the elderly and community based psychiatric services. From time to time prioritisation is coming up as a topic, but it seems that it is still a too complicated issue to handle properly, not only by lay people and politicians, but also by the professionals. Cross-borders patient "tourism" has not yet emerged as a big challenge as it possibly may be in a short time in Europe due to the common European legislation on provision of services across national borders.

\section{CORE ELEMENTS IN HEALTH CARE LEGISLATION}

The responsibility for different public bodies to establish defined types of health care is described in the legislation. The extent of services provided in an individual case is a balance between the provider's obligation to deliver services of sound professional standards and each patient's need for health care, based upon an individual assessment.

According to section 4 in the act related to health personnel health services shall be provided on basis of sound professional practice. The principle of sound professional practice is to be regarded as a legal standard, more or less like the "reasonable man standard" well known from tort law. The legislation does not specifically define how the standard of sound professional 
practice shall be interpreted. The interpretation has to build upon current professional judgements, based on tradition, scientific evidence and ethical considerations.

Section 4 is perhaps the most important rule regulating professional work in the health sector in Norway. The two first parts of this section may be translated from the Norwegian language in this way:

"Health personnel shall conduct their work in accordance with the requirements to professional responsibility and diligent care that can be expected based on their qualifications, the nature of their work and the situation in general.

Health personnel shall act in accordance with their professional qualifications, and assistance shall be obtained and patients shall be referred on to others if this is necessary and possible. If the patient's needs so indicate, the profession shall be performed through cooperation and inter-action with other qualified personnel."

In addition the patient's own wishes shall be considered, and the patient shall be able to choose between possible different justifiable treatments. But the patient is not allowed to have a free choice of health care according to his or her own judgements or wishes. The assessment of the needs of the patient shall be related to professional judgements e.g. from a medical and a nursing point of view.

All provision of health care is to be based upon a valid consent from the patient. Deviations from this principle require authority in written law. Two examples of such situations will be described below.

It finally has to be mentioned that the Norwegian legislative system is based upon the Central European principle of statutory, written laws. The common law principle known from Anglo-American legislation is not a guiding principle, even though someone may argue that the extensive use of legal standards have some resemblance with and is based on this tradition.

\section{ROLES FOR THE MEDICAL PRACTITIONER}

The first legislation related to medical practitioners in Norway is as old as from 1672, even though at that time the number of medical practitioners was very low. The reason why it still is worth mentioning is that this old set of legislation defines at least two different roles for the medical practitioner. And even today we may identify these roles in current legislation.

First of all we find the role as "clinician", providing medical investigations, giving advice and treatment according to the wishes and needs of the single patient, based on professional knowledge, skills and attitudes. A leading norm 
in this role is acting in the interest of the patient. Certainly this is a central part of the Hippocratic tradition.

But secondly we can identify the role as "public servant", giving medical advice to the society, and on behalf of the society to use medical measures for controlling or regulating purposes. These two roles are not always easy to combine, neither from an ethical or a practical point of view. The possible ethical considerations related to conflicting roles will not be discussed further here, even though they are very important both principally and in practice. Here it shall only be mentioned that if the medical practitioner as "clinician" shall engage in other activities than those in the pure interest of the patient, this has to be authorised by written law.

In Norwegian legislation the medical practitioner's role as "public servant" is imminent in a lot of situations, e.g. when giving medical evaluations related to driver's licensing or economic benefits at sick-leave from work; and certainly when dealing with patients with serious mental diseases and communicable diseases hazardous to public health. These two cases will be discussed below.

\section{COMPULSORY PSYCHIATRIC TREATMENT}

The current legislation related to compulsory treatment of patients with psychiatric disorders came into force in 2001. The new legislation focused the rights of the patient during the process leading forward to a decision of compulsory psychiatric treatment. After evaluation this legislation was revised by the Parliament in December 2006. During this revision the procedural rights for the patient were clarified even more.

The main principle is that patients needing psychiatric care should receive that just like receiving other types of health care, based upon valid consent and through delivery of necessary services according to sound professional standards. Only if it is not possible to gain consent, compulsory clinical investigation or treatment may be considered.

The requirements related to compulsory clinical investigation will not be considered further here. For implementing compulsory treatment the psychiatric care act specifies the following absolute criteria:

- the patient must have a severe psychiatric disorder (in practice interpreted as psychosis), and due to this disease;

- the patient must spoil possibility for significant recovery if not treated or on short terms constitute a serious danger for the life or health of other persons or himself.

These criteria obviously have to build on professional judgement, but for this judgement to be valid, it is not enough that it is done according to 
sound professional practice. It also has to be done according to at set of very specific procedural criteria described in the legislation.

First of all the clinical investigation leading forward to the judgement must be required either by the relatives of the patient, or by a public authority. The relevant authorities and the set of relatives in position to require this investigation are defined in the law.

Secondly this primary clinical investigation has to be carried out by a medical practitioner not adhered to the psychiatric care provider that potentially shall provide the compulsory care. The results of this investigation shall be presented in written documentation to the psychiatric care provider. This judgement is not regarded as a public decision. But as a professional judgement given by a medical practitioner, it may be claimed for evaluation by the governmental health care supervisory authority (Norwegian Board of Health Supervision).

Thirdly a qualified psychiatrist (or psychologist) must agree with the judgement of the first investigator that the criteria for compulsory treatment are fulfilled. This judgement shall build upon a personal medical investigation of the patient, independent form the first investigation outside of the hospital. Thereafter a formal decision shall be made if compulsory treatment shall be enacted.

The decision of implementing compulsory treatment shall be documented in written form and presented to the patient with information on complaint procedures. This is regarded as a public decision made by the hospital on behalf of the state (government).

At last this decision may be appealed first to a special complaint board, and possibly further on to ordinary courts.

At very point in this process the patient shall be informed and given the opportunity to pose own views on the situation. Further more the patient is entitled to engage a lawyer after own choice to assist him or her. The expenses related to this help are to be covered by the public authorities.

\section{COMPULSORY MEASURES RELATED TO CONTAGIOUS DISEASES}

The current legislation on contagious diseases dates back to 1994. The act relating to protection against contagious diseases at that time replaced a set of different acts and regulations, the oldest from 1860. Former separate legislation on different types of diseases (e.g. tuberculosis, sexually transmitted diseases) was abandoned. All types of diseases and public measures are covered by the new act. 
New contagious diseases emerging, not least aids, posed new challenges not covered by the former legislation. One of the main concerns was that the former legislation did not state any norms relating to compulsory clinical investigation, treatment or isolation of individuals. And as a result thereof there were no procedural requirements specified in the legislation.

The aims of the act relating to protection against contagious diseases are protection of the population against communicable diseases, ensuring information and treatment to potential patients, regulating compulsory measures related to individuals and defining responsibilities for different actors and institutions.

The set of possible compulsory measures are including medical investigation for diagnosing contagious diseases, isolation in hospital, immunisation and denying of work e.g. in food industry or health care.

Compulsory measures are only possible to enforce if the disease of concern is regarded as a communicable disease hazardous to public health. Which diseases that fulfil this criterion are defined by regulations authorised in law.

The act further clarifies the rights and the obligations of patients or possibly infected persons. This includes the right to receive information and medical assistance including vaccinations and treatment. Among the obligations is the duty for the patient to contact a medical practitioner as soon as possible when he or she suspects having a contagious disease hazardous to public health. There is also described a duty for the patient to follow the advice given by the doctor.

According to this act, as with compulsory treatment of psychiatric diseases, before enacting compulsory measures voluntary co-operation shall have been tried.

Compulsory measures may then be taken if they are necessary to prevent transmission of the disease, and they are justifiable on basis of medical knowledge, and not imposing unreasonable harm to the persons involved, and they are restricted in time.

The municipal public health officer is in a very central position according to this act. He or she is obliged to initiate the work with individual cases when necessary. The public health officer is typically a medical practitioner specialised in community medicine. This officer shall co-operate with a hospital based specialist in infectious diseases when evaluating individual cases.

The professional judgements of these two doctors shall be forwarded to a national commission through the regional governmental authorities (county governor and county medical officer). This national commission make the formal decision in each single case. The decision by this commission may be appealed to ordinary courts. The patient may be assisted by a lawyer chosen 
by the patient through the process and the expenses connected with this are covered by public authorities.

\section{DISCUSSION}

Restrictions of individual rights due to medical reasons are quite often necessary in order to protect public interest. The two sets of norms presented above show some common principles used in the Norwegian legislation to make a trade-off between the individual rights and the public needs. These principles may be summed up as follows:

- The main principle is that if it is possible to gain voluntary co-operation from the patent, the medical interventions shall be based on valid consent.

- Possible restrictions on the individual shall be reasonable based on current medical knowledge, and comply with the general principle in Norwegian health legislation that all services shall be according to sound professional standards.

- The restrictions shall not be more extensive in time and content than necessary and reasonable related to the purpose with the measures.

- The persons who are restricted in their freedom shall enjoy a health care of best possible standard (and free of charge).

- The processes leading to the restrictions must be defined in the legislation. They must be predictable, transparent and documented in written form in the single case.

- The decisions must be able to appeal, not only to an independent administrative board or commission, but also to the ordinary courts.

\section{CONCLUSION}

The role of the medical practitioner as a controller on behalf of the society must be under continuous scrutiny. The limits for the power of the doctor in such roles must me clearly defined in the legislation and co-ordinated with the procedural rights of the patient. This means that medical practitioners through their education not only must gain knowledge and skills in performing the medical judgements, but also a thorough knowledge of the frames that shall border these judgements. The medical judgements may be defined as "legal standards", but the procedures have to be clearly expressed through statutory law. 